\title{
Conceivability, possibility and the resurrection of material beings
}

\author{
Thomas Atkinson ${ }^{1}$
}

Received: 29 March 2016/Accepted: 18 May 2016/Published online: 31 May 2016

(C) The Author(s) 2016. This article is published with open access at Springerlink.com

\begin{abstract}
In his 1998 postscript to 'The Possibility of Resurrection' Peter van Inwagen argues that the scenario he describes by which God might resurrect a human organism, even though probably not true (cf. van Inwagen in, The possibility of resurrection and other essays in Christian apologetics, Westview Press, Boulder, 1998 b, p. 51), is still conceivable and, consequently, 'serves to establish a possibility' (van Inwagen in, The possibility of resurrection and other essays in Christian apologetics, Westview Press, Boulder, 1998b, p. 51), namely, the metaphysical possibility of the resurrection of material beings. Van Inwagen, however, has also argued in favour of 'modal scepticism' [van Inwagen in, God, knowledge and mystery: essays in philosophical theology, Cornell University Press, Ithaca 1995b, pp. 11-12; van Inwagen in, Philos Stud 92:67-84 (69), 1998a]. That is, he thinks that we should limit all our claims about what is possible to 'ordinary propositions about everyday matters' (van Inwagen in, Philos Stud 92:67-84 (76), 1998a). In this paper I argue that van Inwagen's modal argument as found in 'The Possibility of Resurrection' (van Inwagen in, The possibility of resurrection and other essays in Christian apologetics, Westview Press, Boulder, 1998b) is inconsistent with his modal scepticism as found in 'Modal Epistemology' (van Inwagen in, Philos Stud 92:67-84, 1998a). In consequence, I argue that, given his modal scepticism, the task van Inwagen set himself in 'The Possibility of Resurrection' (to establish the possibility of the Resurrection) has not been achieved.
\end{abstract}

Keywords Modality · Death $\cdot$ Survival · Animalism · Modal epistemology

Thomas Atkinson

t.atkinson@liverpool.ac.uk

1 Mulberry Court, University of Liverpool, Mulberry Street, Liverpool L69 7ZY, UK 
In his 1978 paper 'The Possibility of Resurrection' Peter van Inwagen argued that, although the resurrection seems, given his materialist metaphysics, to be impossible for God to achieve, an argument can be made to demonstrate that this is not actually the case. Van Inwagen's method was to put forward 'a metaphysically possible story, in which God accomplished the Resurrection of the Dead' (van Inwagen 1998 b, p. 50) that he hoped would convince his readers that although the resurrection may, on first appearances, seem impossible it is not actually so. Not only this, but, initially, van Inwagen suggested that he thought that the metaphysically possible story that he gave to describe how God could achieve the resurrection of material beings was the 'only way such a being could accomplish it' (van Inwagen 1978, p. 121).

Many arguments have been offered in response to van Inwagen's (1978) paper. Most of these arguments have served to demonstrate that the description of the resurrection that van Inwagen put forward entails some strange or 'unseemly' (Zimmerman 2010, p. 33) conclusion and, consequently, should not be considered to be the actual mechanism by which God would resurrect human organisms from the dead. Since then, however, van Inwagen has argued in his 1998 postscript to his paper 'The Possibility of Resurrection' that although the model of the resurrection that he originally put forward 'isn't true' (van Inwagen 1998b, p. 51) and is not the 'only way' (van Inwagen 1978, p. 121) God could achieve the resurrection, it still 'serves to establish a possibility' (van Inwagen 1998b, p. 51). That is, the model still serves to demonstrate that it is possible for God to resurrect human organisms from the dead. Consequently, van Inwagen's argument put forward in 'The Possibility of Resurrection' still stands and it is incumbent on critics of van Inwagen to demonstrate that the story he put forward in 'The Possibility of Resurrection' is somehow metaphysically incoherent.

This paper is another response to van Inwagen's argument put forward in 'The Possibility of Resurrection.' In this paper, however, I will not attempt to demonstrate that van Inwagen's story entails some unseemly conclusion. Neither will I attempt to argue that his story is somehow metaphysically incoherent. Instead I will attempt to argue that van Inwagen has not yet established, as he thinks he has, that it is metaphysically possible for God to achieve the resurrection of human organisms because van Inwagen, given his modal scepticism, should be sceptical of the claim that it is possible for God to resurrect human organisms.

I will carry out this project as follows. First, I will outline van Inwagen's materialist metaphysics of the human person, the problem posed by his materialist metaphysics for the doctrine of the resurrection and van Inwagen's modal solution to this problem. Second, I will outline van Inwagen's modal scepticism. Third, I will argue that, given his modal scepticism, van Inwagen should be sceptical of his claim that it is possible for God to resurrect human organisms and, in consequence, should not claim that he has established that it is possible for God to resurrect human organisms. Finally, I will consider some objections to my argument and respond to them. 


\section{van Inwagen's argument for the possibility of resurrection}

In his book Material Beings van Inwagen puts forward his materialist metaphysics of the human person. Put simply, van Inwagen thinks that we, human persons, are human organisms. Human organisms are material objects composed entirely of material simples (such as quarks, electrons, gauge bosons, etc.). Material simples come to compose a human organism in virtue of their getting 'caught up' (van Inwagen 1990, p. 94) in a life. More precisely, a human organism is composed of simples the activities of which constitute a life. A life is a self-organising homeodynamic event that maintains an organism's complex internal structure.

Van Inwagen also puts forward a materialist criterion for the persistence of organisms across time. Van Inwagen calls this criterion Life. He states this criterion as follows (let 'the xs' be one group of material simples and 'the ys' be another group of material simples):

Life $=$ 'if the activity of the $\mathrm{xs}$ at $\mathrm{t}_{1}$ constitutes a life, and the activity of the ys at $t_{2}$ constitutes a life, then the organism that the $x$ compose at $t_{1}$ is the organism that the ys compose at $t_{2}$ if and only if the life constituted by the activity of the $\mathrm{xs}$ at $\mathrm{t}_{1}$ is the life constituted by the activity of the ys at $\mathrm{t}_{2}$ ' (van Inwagen 1990, p. 145).

This criterion, however, creates a problem for van Inwagen concerning the doctrine of the general resurrection, which is a doctrine that van Inwagen wants to retain. As van Inwagen notes, the problem seems to be that, given Life and 'given certain facts about the present age' (van Inwagen 1998b, p. 45)—namely, that when human organisms die their lives cease and their corpses rot-this 'of necessity, yield[s] the result that many men who have died [in] our own life time and earlier will not be found among those who live after the Last Day'(van Inwagen 1998b, p. 45). This is because (given Life) for any organism, A, at one time, $\mathrm{t}_{1}$, to be identical with an organism, $\mathrm{B}$, at another time $\mathrm{t}_{2}$ the simples that compose $\mathrm{A}$ at $\mathrm{t}_{1}$ need to be caught up in the same life as that in which the simples that compose $B$ at $t_{2}$ are caught up. However, as soon as a particular organism dies naturally and it is, for example, subject to the normal room-temperature processes of biological decay for, say, fifteen minutes (or, it, for example, dies by being blown to bits by a bomb) then that organism's life ceases and, according to van Inwagen, 'can never begin again' (van Inwagen 1990, p. 147). Van Inwagen calls this mode of death 'disruption' (van Inwagen 1990, p. 147). Consequently, any particular organism, B, that exists after the time of death (disruption) of a particular organism, A, cannot be identical with A.

Consider the following example. Mary has died from a heart attack and her corpse $^{1}$ has been subject to the normal room-temperature processes of biological

\footnotetext{
1 Strictly speaking, given van Inwagen's metaphysics of material constitution, there is no corpse. Just a pile of simples arranged humanwise. For the sake of ease in this paper I will continue to use 'corpse' as shorthand for, either, a 'pile of simples arranged humanwise that were recently caught up in a life', or, (also as shorthand for) 'living-corpse' (van Inwagen 1990, p. 147); that is, an organism that still exists in virtue of its having its life 'squeezed' (van Inwagen 1990, p. 147) (this will be further discussed below). It will be clear in the course of this paper what kind of corpse I am referring to.
} 
decay for fifteen minutes (processes that, it seems, the vast majority of our bodily remains will be subject to). It may seem to many as though God could simply repair the damaged organs of Mary's corpse and cause the simples that virtually ${ }^{2}$ compose her corpse to be caught up in a life again and that this would be sufficient for Mary (the very same person that died) to be made alive again. Van Inwagen, however, disagrees. Van Inwagen argues that this life will be a new life. This is because Mary's life has been disrupted and any life going on after disruption will not be Mary's life. Thus, God's causing the simples that virtually compose Mary's corpse to be caught up in a life again will not suffice for this organism to be identical with Mary.

Why should we think of the life that God starts as a new life and not Mary's original life? Van Inwagen writes that it is because this life will be a result of 'God's miracle and not because of the operations of the natural processes that, taken collectively, were the life of' (van Inwagen 1998b, p. 47), in our case, Mary. The underlying assumption here seems to be that in order for a life at one time to be identical with a life at another time the activities of the simples that constitute these lives need to be immanent-causally connected. Indeed, van Inwagen writes, speaking of himself as identical with an organism that exists after his death, 'there will have to be some sort of material and causal continuity between this matter that composes me now and the matter that will then compose that man' (van Inwagen 1995a, p. 486). God's restarting the life of a corpse that has been subject to the normal room-temperature processes of biological decay for fifteen minutes, however, requires that He supply the relevant causal processes to a pile of simples arranged humanwise to get caught up in a life and, it seems in this case, there are no sufficient immanent causal connections between the constituents of these lives. Consequently, Mary and any other human organism that dies in the usual way (disruption) cannot be made to be alive again and so cannot be resurrected. Moreover, any organism that dies in a more traumatic way (for example, by being blown to bits by a bomb) a fortiori cannot have its life begin again either. Van Inwagen concludes by saying that it is absolutely impossible, even as an accomplishment of God, that a man who has been burned to ashes or been eaten by worms should ever live again' (van Inwagen 1998b, p. 48).

Van Inwagen's solution to this problem is to demonstrate that while Life is true “"certain facts about the present age" are not facts' (van Inwagen 1998b, p. 49); in particular, the supposed fact that when human organisms die their lives get disrupted. Rather, the disruption of life upon death is only, perhaps, apparent. In his paper 'The Possibility of Resurrection' van Inwagen argues just this. He does this by providing what he thinks is a metaphysically possible story in which human organisms 'die' but their lives do not get disrupted. In doing so, he takes himself to have established a possibility (namely, that it is possible for God to resurrect human organisms from the dead) and, therefore, takes himself to be justified in asserting that it is possible for God to resurrect human organisms from the dead.

\footnotetext{
${ }^{2}$ I say 'virtually' compose her corpse because, given van Inwagen's metaphysics, they don't actually compose anything.
} 
Before I describe this metaphysically possible story, however, I will briefly outline what I take metaphysically possible stories, in general, to be and how they might function in arguments to justify some subject S's assertion that some proposition $p$ is possible and, therefore, enable $\mathrm{S}$ to say that she has 'established a possibility'.

A metaphysically possible story is a story that, since it is conceivable, serves to justify the assertion of the possibility of a certain proposition that that story describes. A story of this kind can be offered in what I call an 'argument from conceivability to possibility' or a 'conceivability argument'. Take, for example, the proposition: flying pigs exist, and the following story and the accompanying conceivability argument. Imagine that one day Alice successfully breeds a pig with a large bird. The offspring produced by this breeding process results in the existence of a pig with wings. This pig takes a running jump off a cliff, flaps its wings and flies. One may then argue that if this story is conceivable for one then it follows that one is prima facie justified in asserting the possible truth of the proposition: flying pigs exist. That is, asserting: it's possible that flying pigs exist.

One way the structure of a conceivability argument (such as the above argument) can be represented is as follows:

\section{Conceivability argument structure}

$\mathrm{P} 1$. For any proposition, $p, \mathrm{~S}$ is prima facie justified in asserting the possible truth of $p$ if $\mathrm{S}$ takes herself to have conceived of a world that verifies $p$.

P2. $\quad \mathrm{S}$ has conceived of a world $w$ that $\mathrm{S}$ takes to verify $p$.

\section{Therefore,}

C. $\mathrm{S}$ is prima facie justified in asserting that it is possible that $p$.

Premise P1 is the key premise. This premise assumes a particular account of the basis of modal knowledge. That is, it assumes a particular account of what it takes for some subject $\mathrm{S}$ to be prima facie justified in asserting that a particular proposition $p$ is possibly true. According to $\mathrm{P} 1 \mathrm{~S}$ is justified in asserting that a particular proposition $p$ is possibly true if $S$ takes herself to have conceived of a world $w$ that $\mathrm{S}$ takes to verify $p$. The account of what it takes for some subject $\mathrm{S}$ to be justified in asserting the possible truth of a particular proposition $p$ that I assume in this paper (and is assumed in P1) is Stephen Yablo's account of the basis of modal knowledge (Yablo 1993). It will become clear why I assume this account shortly. According to Yablo's account, a proposition $p$ is conceivable for $\mathrm{S}$ if $\mathrm{S}$ can imagine a possible world $w$ that $\mathrm{S}$ takes to verify $p$. I will call this 'Yablo-Style conceivability.'

The metaphysically possible world $w$ that $\mathrm{S}$ takes to verify $p$ is referred to in premise $\mathrm{P} 2$ and, given $\mathrm{P} 1$, so long as this world $w$ is Yablo-style conceivable for $\mathrm{S}$, it follows that $\mathrm{S}$ is justified in asserting the possible truth that $p$. C follows from $\mathrm{P} 1$ 
and P2 by modus ponens. I will refer to some subject's asserting the possible truth of some proposition $p$ as a 'possibility-claim'. In consequence, I will prefix ' $p$ ' with 'possibility-claim' when I mean to denote the assertion of the possible truth of some proposition. For example, when one takes oneself to have imagined a world at which the following proposition $p^{1}$ 'Flying pigs exist' is verified, I shall say that one is justified in asserting the possibility-claim $p^{1}$ (i.e., justified in asserting: it is possible that flying pigs exist).

In his paper 'The Possibility of Resurrection', then, van Inwagen seems to be putting forward a conceivability argument (of the kind above). Van Inwagen describes a metaphysically possible story ${ }^{3}$ (that I will refer to as $w^{\prime}$ ) that he takes to verify the proposition (that I will refer to as $p^{\prime}$ ): God resurrects human organisms. Not only this, but van Inwagen hopes that his readers will grant that it is a metaphysically possibly story (cf. van Inwagen 1998b, p. 50). Accordingly, he hopes to have demonstrated that he (and anyone else that can imagine the story he tells) is justified in asserting the possible truth of $p^{\prime}$ and so will accept that he has established the possible truth of $p^{\prime}$.

The metaphysically possible world that van Inwagen puts forward to verify $p^{\prime}$ has come to be known as the 'simulacrum story'. To avoid misstating the metaphysically possible world $w^{\prime}$ that van Inwagen takes to verify $p^{\prime}$ I quote the passage in full.

It is part of the Christian faith that all men who share in the sin of Adam must die. What does it mean to say that I must die? Just this: that one day I shall be composed entirely of nonliving matter; that is, I shall be a corpse. It is not part of the Christian faith that I must at any time be totally annihilated or disintegrate. (One might note that Christ, whose story is supposed to provide the archetype for the story of each man's resurrection, became a corpse but did not, even in his human nature, cease to exist.) It is of course true that men apparently cease to exist: those who are cremated, for example. But it contradicts nothing in the creeds to suppose that this is not what really happens, and that God preserves our corpses contrary to all appearance. Perhaps at the moment of each man's death, God removes his corpse and replaces it with a simulacrum, which is what is burned or rots. Or perhaps God is not quite so wholesale as this: Perhaps he removes for 'safekeeping' only the 'core person' - the brain and central nervous system -or even some special part of it. These are the details.

\footnotetext{
3 I use the terms, 'story,' 'scenario,' 'model,' and 'world' interchangeably. This is primarily because van Inwagen and Yablo use these terms and, as far as I can tell, use them synonymously. One might note, however, that there is an important distinction between these terms. One might note that a possible world 'is a whole coherent reality...in which $p$ is true, of which the truth of $p$ is an integral part' (van Inwagen 1998a, p. 77) while a 'story,' 'scenario' or 'model' is merely, say, a part of a seemingly 'whole coherent reality'. This may be how philosophers use the terms, however, when we commit $S$ to imagining a possible world at which $p$ is possibly true, we're not committing $\mathrm{S}$ to having imagined a whole coherent reality, but only a part of a seemingly whole coherent reality. That is, we're committing $\mathrm{S}$ only 'to imagin[ing] a $p$-verifying world while leaving matters visibly irrelevant to $p$ 's truth unspecified' (Yablo 1993 , p. 29). To be clear, then, in this paper I take the term 'world' in 'a $p$-verifying world that leaves matters visibly irrelevant to $p$ 's truth unspecified' to be equivalent to a 'story,' 'scenario' or 'model.'
} 
I take it that this story shows that the Resurrection is a feat an almighty being could accomplish (van Inwagen 1998b, p. 49). ${ }^{4}$

We can, then, take the possible world described in the above story and put it into a conceivability argument for the possibility of the resurrection.

\section{The conceivability argument for the possibility of resurrection}

$\mathrm{P}^{\prime}$. For any proposition, $p, \mathrm{~S}$ is prima facie justified in asserting the possible truth of $p$ if $\mathrm{S}$ takes herself to have conceived of a world that verifies $p$.

$\mathrm{P}^{\prime}$. Van Inwagen has conceived of a world $w^{\prime}$ (the simulacrum story) that he takes to verify $p^{\prime}$ (God resurrects human organisms).

\section{Therefore,}

$\mathrm{C}^{\prime}$. Van Inwagen is justified in asserting that it is possible that $p^{\prime}$ (i.e., it is possible for God to resurrect human organisms).

\section{Modal scepticism}

Van Inwagen, however, is a sceptic about modal claims. These are propositions that include modal assertions like 'it is possible' and 'it is necessary.' For the purposes of this paper I am only concerned with possibility-claims. Van Inwagen, however, is sceptical about only some, not all, possibility-claims. Van Inwagen thinks that we should not be sceptical about possibility-claims asserted by philosophers regarding 'ordinary propositions about everyday matters' (van Inwagen 1998a, p. 76). Claims like: it's possible that the table have been two feet to the left of where it in fact was. He thinks we need not be sceptical of these claims because, so it seems, these claims are not 'remote from the practical business of everyday life' (van Inwagen 1998a, p. 70), our knowledge of them is 'non-inferential,' (van Inwagen 1998a, p. 70) and, they express 'no intrinsic impossibility' (van Inwagen 1998a, p. 70). These claims, then, can be taken to be 'basic' (van Inwagen 1998a, p. 73) and, therefore, prima facie justified. ${ }^{5}$ I will call the set of propositions that has as its members basic possibility-claims 'BP.'

Van Inwagen doubts, however, that philosophers are also prima facie justified in asserting possibility-claims that are far-removed from the practical business of

\footnotetext{
4 There are, perhaps, two metaphysically possible stories here. (i) God preserves a whole corpse and (ii) God preserves a part of a corpse. This distinction is important but it should not matter for this paper. In this paper I will assume (i) but my arguments can apply to (ii). To find out more about (ii) one should see (Atkinson 2015; Anders 2011).

5 It should be noted that van Inwagen does not discuss the justificatory status of basic modal claims as I have done. He merely argues that we know these claims non-inferentially. This should not matter for my purposes, however, because I assume that for $\mathrm{S}$ to know $p$ entails that $\mathrm{S}$ is justified in believing $p$.
} 
everyday life. Claims such as: it's possible for naturally purple cows to exist. I will call the set of propositions that has as its members possibility-claims that are farremoved from the practical business of everyday life 'FP' ${ }^{6}$ Van Inwagen thinks that we should be sceptical of claims like these because he thinks that 'we have no sort of capacity that would enable us to know' them (van Inwagen 1998a, p. 70). Or, to put it another way, there is no adequate 'source' (van Inwagen 1998a, p. 73) (or, perhaps, combination of sources) that would enable us to know these exotic possibility-claims.

That said, van Inwagen does, however, think that there is an account of the source of modal knowledge that he says 'has some very attractive features, and is certainly more sophisticated than any other account of modal knowledge' (van Inwagen 1998a, p. 76). Moreover, he writes of it that 'I am inclined to think that if this account is not the whole truth of the matter, it contains a great deal of the truth of the matter' (van Inwagen 1998a, p. 81). This account is Yablo's account and, importantly, (as demonstrated above) is an account that he seems to be assuming in his argument for the possibility of resurrection. Even so, however, van Inwagen still thinks that Yablo's account 'supports modal scepticism' (van Inwagen 1998a, p. 76). This is because he doubts that many of the possible worlds that philosophers have imagined, that they take to verify exotic propositions, have been adequately imagined.

Given that van Inwagen seems to be assuming something like Yablo's account of modal knowledge when putting forward his argument for the possibility of resurrection, ${ }^{7}$ we can now ask the question that this paper is concerned with; namely, has the world $w^{\prime}$ been adequately imagined so as to verify $p^{\prime}$ ? There are two initial responses that can be given. First, if $w^{\prime}$ has been adequately imagined then $w^{\prime}$ can feature as a world that can be referred to in a conceivability argument verifying $p^{\prime}$ and, van Inwagen, is, consequently, justified in asserting the possibility-claim $p^{\prime}$. Second, if $w^{\prime}$ has not been adequately imagined then $w^{\prime}$ cannot feature as a world that can be referred to in a conceivability argument verifying $p^{\prime}$ and, van Inwagen, is, consequently, not justified in asserting the possibility-claim $p^{\prime}$. I will argue that, given van Inwagen's arguments for his version of modal scepticism, $w^{\prime}$ has not been adequately imagined and, consequently, the possibility-claim $p^{\prime}$ is among FP. Before I attempt to demonstrate that $w^{\prime}$ has not been adequately imagined (given his modal scepticism), however, I must first state the conditions under which van Inwagen thinks some world $w$ has not been adequately imagined. ${ }^{8}$

\footnotetext{
${ }^{6}$ I borrow this terminology from (Hawke 2011).

7 Below (Sect. 4) I will consider objections that argue that even though the possibility-claim $p^{\prime}$ seems to be among FP it can either: (a) be counted among BP or (b) it is among FP but can be known by testimony. There is a third option: (c) it is among FP but can be arrived at by 'reason-operating on a combination of "basic" modal knowledge... and facts about the way the world is put together' (van Inwagen 1998a, p. 70). I will not consider this objection here. This is because van Inwagen would have to argue for (c) and this, so it seems, would require a significant amount of work. Doing this on behalf of van Inwagen is beyond the bounds of this paper.

8 As Hartl notes, van Inwagen does not give 'a clear example of a successful justificatory process via Yablo-style conceivability’ (Hartl 2016). Van Inwagen only tells us, and gives examples, of unsuccessful justificatory processes via Yablo-style conceivability. That is, he only gives examples of worlds that do not count as worlds that have been adequately imagined. I must proceed then in the way just described.
} 
In his paper 'Modal Epistemology' van Inwagen, it seems, gives two arguments as to why one should hold that a particular world $w$ has not been adequately imagined. I will call these arguments 'the structural-detail argument' and 'the compatibility with not- $p$ argument'. Let us consider each argument in turn.

\section{The structural-detail argument}

First, van Inwagen argues that we have not adequately imagined a world $w$ if our imaginings have not 'take[n] place at a level of structural detail' (van Inwagen 1998a, p. 79). Van Inwagen considers two propositions and two imagined worlds that supposedly verify these propositions and demonstrates that these worlds have not been imagined at a level of structural detail sufficient to verify those propositions.

First, van Inwagen considers the following proposition: naturally purple cows exist. Van Inwagen argues that in order to conceive of a world that verifies the above proposition we would need to imagine 'a chemically possible purple pigment such that the coding for the structures that would be responsible for its production and its proper placement in a cow's coat could be coherently inserted into any DNA that was really cow DNA-or even- “cow-like-thing-but-for-color" DNA' (van Inwagen 1998a, p. 78). Van Inwagen, however, is doubtful that anyone has, or can, given our present knowledge, perform this imaginative exercise and, in consequence, concludes that, "if a philosopher has not attempted to do something like this, then that philosopher has not, in any useful sense, attempted to imagine a possible world in which there are naturally purple cows' (van Inwagen 1998a, p. 78). Consequently, van Inwagen concludes that if Yablo-style conceivability is true, and if he is right that in the present state of knowledge no one is able to imagine a possible world in which there are naturally purple cows, then it follows that 'no one is even prima facie justified in believing that naturally purple cows are possible' (van Inwagen 1998a, p. 78).

Second, van Inwagen considers the following proposition: transparent iron exists. As with the purple-cow case, van Inwagen thinks that the world that the imaginer might take to verify the above proposition has not been imagined to a sufficient level of structural detail. In order to conceive of the existence of transparent iron to a sufficient level of structural detail, van Inwagen suggests one would have to imagine a world that contains transparent iron with the 'structural detail comparable to that of the imaginings of condensed-matter physicists who are trying to explain, say, the phenomenon of superconductivity' (van Inwagen 1998a, p. 79). Again, van Inwagen argues that 'so far as I know no one has imagined, at the necessary level of structural detail, a world-whether its laws are the actual laws or some others-in which there is transparent iron' (van Inwagen 1998a, p. 80). Again, in conclusion, van Inwagen will argue that given that no one is, given the current state of our knowledge, able to imagine a possible world in which there exists transparent iron

Footnote 8 continued

That is, I cannot say what it takes for some world to have been adequately imagined. I can say only what it takes for some world not to have been adequately imagined. This, I think, will suffice for my purposes. 
then it follows that no one is even prima facie justified in believing that the production of transparent iron is possible.

\section{The compatibility with not-p argument}

Van Inwagen offers a second argument why one should hold that a particular world $w$ has not been adequately imagined in order to verify some proposition $p$. Van Inwagen argues that we have not adequately imagined a world $w$ that we can take to verify $p$ if our imaginings are compatible with its being the case that not- $p$.

Consider the example of transparent iron again. If our imagining of a world at which there exists transparent iron consists of, say, our imagining a world where 'we imagine a Nobel Prize acceptance speech in which the new Nobel laureate thanks those who supported him in his long and discouraging quest for transparent iron and displays to a cheering crowd something that looks (in our imaginations) like a chunk of glass, we shall indeed have imagined a world, but it will not be a world in which there is transparent iron'(van Inwagen 1998a, p. 79). This is because this imagined scenario is compatible with, for instance, the background scenario that transparent iron does not exist, but the scientific community has somehow been deceived into thinking that it does. The Nobel-Prize winning scientist might, for example, merely be holding up a pane of glass while everybody in the room believes that it is transparent iron.

The compatibility-with-not- $p$ argument functions in two ways. First, it functions as an argument, on its own, to establish that some imagined world $w$ has not been sufficiently imagined so as to verify $p$. Second, however, it also functions as an argument to support the structural-detail argument. That is, one might ask the question 'how do we know when we've imagined some world $w$ to a sufficient level of structural detail so as to verify $p$ ?'. One response is to ask the question 'is this scenario compatible with not- $p$ ?'. If it is then one, according to van Inwagen, has certainly not imagined the scenario to a sufficient level of structural detail.

This still leaves the following question open, however: how do we know when we've imagined some world $w$ to a sufficient level of structural detail so as to verify $p$ when it's not clear whether or not $w$ is compatible with not- $p$ ?. Van Inwagen does not give an explicit answer to this question. However, given what he says in 'Modal Epistemology', I think we can conclude that it would be something along the lines of the following:

Has the imaginer imagined $w$ to the level of structural detail that an expert in the relevant scientific field concerned with verifying $p$ would have imagined $w$ ?

If the answer is 'yes' then $p$ has been verified; if 'no' then it has not. I say this because van Inwagen's two examples (the purple-cow example and the transparentiron example) both require the imaginer to have imagined the world to the level of structural detail that an expert in the relevant field of scientific enquiry would have imagined that world. In the transparent-iron example, for instance, van Inwagen says that in order to be justified in asserting that it is possible that transparent iron 
exists one would have to imagine a world that contains transparent iron with the 'structural detail comparable to that of the imaginings of condensed-matter physicists'(van Inwagen 1998a, p. 79). Moreover, in the naturally-purple-cow case van Inwagen argues that he doubts the philosopher has imagined the world at which there is a naturally purple cow to the level of structural detail concerning 'the coding structures that would be responsible for [the purple pigment and] its production and its proper placement in a cow's coat' (van Inwagen 1998a, p. 78). This is a level of detail that, I'd expect, could be achieved only by a scientist working in the area of genetics or microbiology. In sum, it seems that, according to van Inwagen, for any proposition $p$, if the imagined world $w$ that one takes to verify $p$ has not been imagined to a sufficient level of structural detail, or is compatible with not- $p$, then the possibility-claim $p$ should be considered among FP.

\section{Modal scepticism and the possibility of the resurrection}

We can now return to our question: does the possibility-claim $p^{\prime}$ belong to FP? Given my above discussion in order to answer this question we need to answer the following further questions. First, 'has the world $w^{\prime}$ that verifies $p^{\prime}$ been imagined to a sufficient level of structural detail?' Second, 'has $w^{\prime}$ been imagined to a sufficient level of structural detail such that it rules out the compatibility of $w^{\prime}$ with not- $p^{\prime}$ ?'.

The answer to the first question, prima facie, seems to be, 'no'. One reason for this is that we're still left with several questions about the details of $w^{\prime}$ that remain unanswered. What does it take for God to remove some organism O's corpse? Or, what does it take for God to replace O's corpse with a simulacrum? Are we to believe that van Inwagen has imagined this scenario in some structural detail comparable to that of the imaginings of, say, an astrophysicist examining the pressures and strains on an organism traveling to the outer reaches of space? Are we to believe that van Inwagen has imagined the preservation processes that God would have to carry out in order to preserve a corpse for thousands of years that would enable it to have its life begin again?

Posing these questions does not demonstrate that van Inwagen has not imagined $w^{\prime}$ to a sufficient level of structural detail so as to verify $p^{\prime}$, nor does it demonstrate that imagining $w^{\prime}$ is compatible with its being the case that not- $p^{\prime}$. To do this we need to point out where the relevant detail is lacking in the story and/or describe how it is that $w^{\prime}$ is compatible with not- $p^{\prime}$. I think there are several areas of detail that one would expect to find (but that we don't get) in van Inwagen's simulacrum story that, given further discussion, might lead to our viewing $w^{\prime}$ as not having been imagined to a sufficient level of detail so as to verify $p^{\prime}$, or might lead to our thinking that $w^{\prime}$ is compatible with not- $p^{\prime}$. It is sufficient for our purposes, however, to point out just one area of van Inwagen's simulacrum story that has not been adequately imagined. In what follows, I focus on, the preservation and resuscitation of the corpse.

A part of God's task, according to the simulacrum story, would be to preserve the corpses of the dead such that the processes of biological decay would stop before progressing too far. How will God preserve the corpses of the dead? Van Inwagen's 
simulacrum story doesn't tell us. Cryogenic freezing, however, seems to be the best candidate explanation that we have to help us conceive of this scenario. I say this for two reasons. First, cryogenic freezing seems to be a method that lends itself well to the task of explaining how God could preserve the corpses. Second, the example of a cryogenically frozen corpse is the only example that van Inwagen gives of a corpse that has been preserved in a way that is sufficient for the continuation of that particular corpse's life. ${ }^{9}$ Upon the cryopreservation of a cat, for example, van Inwagen writes,

I find it attractive to suppose that the cat's life persists even when the cat is frozen. I would describe the frozen cat's life this way: Before the cat was frozen, its life consisted mostly of chemical reactions and various relatively large-scale physical processes (the breaking and establishing of chemical bonds, the movement of fluids under hydraulic pressure, the transport of ions); when the cat was frozen, its life was "squeezed into" various small-scale physical processes (the orbiting of electrons and the exchange of photons by charged particles.) Its life became the sum of those subchemical changes that underlie and constitute chemical and large-scale physical unchange. But the life was there, disposed to expand into its normal state at the moment sufficient energy should become available to it. I, who am fond of oxymorons, would describe the frozen cat as a living corpse (van Inwagen 1990, p. 147).

What is it about a particular cryogenically frozen corpse that is sufficient for the persistence of its life? It seems that, according to van Inwagen, it is the 'various small-scale physical processes' that are sufficient for the continuation of that corpse's life. That is, even though these 'small-scale physical processes' (e.g., the orbiting of electrons and the exchange of photons by charged particles) are not equivalent to the 'large-scale physical processes' (e.g., the breaking and establishing of chemical bonds, the movement of fluids under hydraulic pressure, the transport of ions) that are typical of life, the life, as van Inwagen notes, is still 'there' (van Inwagen 1990, p. 147), but has been 'squeezed' (van Inwagen 1990, p. 147). Consequently, van Inwagen calls a corpse that has been frozen before the processes of biological decay have progressed too far a 'living corpse' (van Inwagen 1990, p. 147).

Van Inwagen realizes, however, that there are some who may argue that because the large-scale physical processes that are typical of a life have ceased, it is contrived to say that the organism that has been cryogenically frozen (a living corpse) 'is alive' (van Inwagen 1990, p. 147). In consequence, van Inwagen allows it to be the case that one can say of an organism that has been cryogenically frozen that its life has been 'suspended' (van Inwagen 1990, p. 147). Van Inwagen writes that 'in general, a life has been suspended if it has ceased and the simples that were caught up in it at the moment it ceased retain-owning to the mere absence of

\footnotetext{
9 William Hasker also supplies van Inwagen's God with this method. He notes, '[a]t death, God plays the part of the practitioners of cryonics, placing the body in suspension to prevent further damage or deterioration. Then at the resurrection, God assumes the role of the future medical rescuers: he reanimates the corpse, heals its fatal injury or illness, and puts the revitalized person on the road to a fuller life' (Hasker Hasker 2001, p. 223).
} 
disruptive forces-their individual properties and relations to one another' (van Inwagen 1990, p. 147). Accordingly, we might say that an organism whose life has been suspended (not disrupted) can have its life begin again, but because its life has ceased (i.e., the large-scale physical processes typical of life have ceased) we can say that the organism is dead. ${ }^{10}$

This distinction between a life that has been squeezed and is still there and a life that has been suspended is, I think, purely terminological. The ontological nature of a corpse that has had its life suspended is the same as a corpse that's had its life squeezed. The simples that compose a corpse that has had its life squeezed and the simples that compose a corpse that has had its life suspended both possess the same (type) 'small-scale physical processes'. The difference is just that there is, for those who prefer to say that the life has been suspended, a 'stipulative sharpening of the meaning of "alive", (van Inwagen 1990, p. 147). For the sake of argument, I will adopt van Inwagen's interlocutor's stipulative sharpening and continue to refer to organisms that have had been cryogenically frozen as organisms whose lives have been suspended.

This is where the problem arises for van Inwagen. A corpse that has not been cryogenically frozen also possesses persistent 'small-scale physical processes' at, for example, the subatomic level. The simples that virtually compose a corpse whose life has been disrupted, for example, still constitute various kinds of smallscale physical processes, and are involved in activity such as the orbiting of electrons and the exchange of photons by charged particles. This being the case, as Jason Eberl notes, although '[v]an Inwagen shares the general intuition that the persistent microlevel activity of an unfrozen corpse is insufficient to characterize it as alive...[h]e allows...the same level of activity in a cryopreserved body to suffice as the life-and the numerically same life-as the organism before its macrolevel life functions were suspended. The only difference van Inwagen cites to differentiate the two cases is that the microlevel activity of a cryopreserved body is "disposed to expand into its normal state at the moment sufficient energy should become available to it"' (Eberl 2008, p. 71). That is, according to van Inwagen, the cryogenically frozen corpse and the corpse that has not been cryogenically frozen are, at least given our current imaginative powers, structurally indistinguishable.

So, the answer to the question of whether the world $w^{\prime}$ that verifies $p^{\prime}$ has been imagined to a sufficient level of structural detail seems to be 'no.' Van Inwagen has not told us what it is about the cryogenically preserved corpse (i.e., anything about the intrinsic properties and relations between the simples that compose the cryogenically preserved corpse) that enables it to have its suspended life begin again that does not also go for a corpse that has not been cryogenically frozen. One might think, though, that in order adequately to have imagined the preservation process to a sufficient level of structural detail so as to verify $p^{\prime}$ one should be able to imagine what it is about the two corpses (a corpse that has been cryogenically frozen and a corpse that hasn't) that disposes one, and not the other, to have its life begin again.

\footnotetext{
${ }^{10}$ This point is contested. See, for example, (Gilmore 2013). One may argue that (as Gilmore does) in this case the organism should be classified as neither dead nor alive. For the purposes of fulfilling van Inwagen's requirement that all those who share in the sin of Adam must die, however, I will classify cryogenic freezing as a form of death.
} 
After all, this is just this level of structural detail that van Inwagen, it seems, requires other philosophers to give of other imagined worlds.

Take, for example, van Inwagen's naturally-purple-cow case. Many know (some in more detail than others) that there is something about a particular cow's DNA that disposes it to be a cow with certain pigmentation. Moreover, many share the general intuition that if we were to change the relevant section of a cow's DNA it would change that cow's colour. But we do not know, precisely, what it would take for, say, purple pigmentation to be inserted into any cow DNA or "cow-like-thingbut-for-colour' DNA. Likewise, many share the intuition that it is something about the microlevel activity of a cryogenically frozen corpse that disposes it to have its suspended life begin again. We do not, however, know what it is, at the level of structural detail concerning the properties and relations between the simples that compose a cryogenically frozen corpse, that enables it to be disposed to have its suspended life begin again. Since I doubt that any philosopher has imagined what it is about a cryogenically preserved corpse that disposes it to have its suspended life begin again, I suggest that, if we accept a version of van Inwagen's modal scepticism, we should not accept that the simulacrum story establishes that it possible for God to preserve the corpse of a human organism in such a way as to ensure that it can have its suspended life begin again.

Whether or not one accepts my argument to demonstrate that $w^{\prime}$ has not been imagined to a sufficient level of structural detail as to verify $p^{\prime}$ on van Inwagen's own terms, there is a further difficulty for van Inwagen. This difficulty concerns the question of whether the world $w^{\prime}$ that verifies $p^{\prime}$ has been imagined in such a way as to rule out the compatibility of $w^{\prime}$ with not- $p^{\prime}$. In other words, are there any other propositions that are consistent with not- $p^{\prime}$ but that are also consistent with one's imagining $w^{\prime}$ ?

I think there are. Take the proposition $p^{\prime \prime}$ that is consistent with not- $p^{\prime}$ : God, on the day of resurrection, causes the simples that virtually compose a particular corpse that he has kept for safekeeping to be caught up in a new life.

In order to demonstrate that $w^{\prime}$ is consistent with $p^{\prime \prime}$ let's assume, again, that God's chosen method of preservation is cryogenic freezing. As mentioned above, however, we do not know what it is about the simples that compose a cryogenically frozen organism that enable it to be disposed to have its suspended life begin again, and what it is about the simples that virtually compose a non-cryogenically frozen corpse that does not enable it to have its life begin again. Since this is the case, it is compatible with our imagining $w^{\prime}$ that the corpse that God resurrects does not in fact meet the relevant conditions for having its life restarted again (since we do not know what it would take for any corpse to meet these conditions). In consequence, it may be the case that, while we think that we've imagined God's preserving a corpse whose life has been suspended, we've actually imagined God's preserving a corpse whose life hasn't been suspended but disrupted; a (virtual) corpse that has been subject to the normal room-temperature processes of biological decay sufficient for disruption and has, perhaps, then been frozen. The simples that virtually compose a corpse such as this, upon resurrection, will get caught up in a new life, a life started by God's miracle. Consequently, in this case, we've not imagined a case of resurrection, but a case of God's bringing a new organism into existence. We've 
imagined $p^{\prime \prime}$ : God, on the day of resurrection, causes the simples that virtually compose a particular corpse that he has kept for safekeeping to be caught up in a new life.

In this respect the simulacrum story seems comparable to the transparent-iron case. Just as the Nobel-prize-winning scientist holds up a (supposed) piece of transparent iron, and this is consistent with its being the case that he is not holding up a piece of transparent iron but a pane of glass, so too our imagining God's resurrecting a human organism according to $w^{\prime}$ is consistent with God's giving a pile of simples arranged humanwise (that were once caught up in a life) a new life.

All that I've written, of course, doesn't establish that it is impossible for God to resurrect human organisms. For all I know it could be the case that the resurrection is possible, given van Inwagen's materialist metaphysics. However, if my argument is correct, it does establish that van Inwagen should be sceptical of the possibilityclaim $p^{\prime}$ and, if this is the case, then van Inwagen has not, as he aimed, 'establish[ed] a possibility' (van Inwagen 1998 b, p. 51). ${ }^{11}$

\section{Objections}

There are several objections that van Inwagen could make to my argument. I will state each objection before offering a response.

Objection 1 Van Inwagen may respond by arguing that he never says that cryogenic freezing is the method that God uses to preserve a corpse, so any objection that I mount against his metaphysics of the resurrection that turns on the nature of a cryogenically frozen corpse is to attack a straw man.

Response Two things must be noted in response. First, as mentioned above, I supplied van Inwagen's God with the process of cryogenic freezing because a corpse that has been cryogenically frozen is the only example that he gives of an organism that has had its life cease but has not had its life disrupted and so can have its life restarted. So, in the absence of any description of this preservation process, I use a process that van Inwagen affirms is plausible. Second, even if we remove cryogenic freezing from the story, my argument still stands. Perhaps, I merely imagine a human organism floating free in space that is seemingly not undergoing any processes of decay. My imagining this scenario (sans cryogenic freezing) is still compatible with its being the case that this corpse was once a human organism that has now had its life disrupted. If this is the case then my then imagining this organism's subsequent animation is not my imagining God's bringing the organism that has died back to life, but God's causing the simples that virtually compose this organism's corpse to get caught up into a new life.

Objection 2 Van Inwagen may argue that one could be justified in asserting the possible truth $p^{\prime}$ even though $\mathrm{S}$ cannot imagine a world that verifies $p^{\prime}$ because

\footnotetext{
11 This, of course, requires something like the following to be true: for any proposition $p, \mathrm{~S}$ cannot take $p$ to have been 'established' if $\mathrm{S}$ is sceptical of the possible truth of $p$. I take this to be uncontroversial.
} 
God, for example, through Scripture, has told her that $p^{\prime}$ is true and God, being infallible, cannot be mistaken about $p^{\prime} .^{12}$

Response In reply, we can simply point out that Scripture does not tell us that $p^{\prime}$ is possible. Scripture does tell us that the resurrection is possible but it does not tell us that materialism with regards to the human person is possibly true (or that the resurrection given a materialist account of the human person is possibly true). Consequently, given that van Inwagen's materialist metaphysics of the human person makes the resurrection seem impossible (even for an omnipotent being) to achieve, in order to be justified in asserting the possible truth of $p^{\prime}$ Scripture would need to tell us that materialism is possibly true (as well as tell us that the resurrection is possible).

Objection 3 van Inwagen may respond by arguing that the possibility-claim $p^{\prime}$ is not, in fact, far-removed at all, but can be counted among BP.

Response Responding to the claim that the possibility-claim $p^{\prime}$ is among $\mathrm{BP}$ is difficult, not least because van Inwagen doesn't explicitly give us any necessary and/or sufficient conditions for saying when a certain possibility-claim can be counted among $\mathrm{BP},{ }^{13}$ besides stating that a possibility-claim can be counted among BP if it is a claim about the 'ordinary,' is known 'non-inferentially' and, contains no 'intrinsic impossibility'.

There is, however, a response. One can note that this would certainly be a strange response to come from van Inwagen. If he thought that the possibility-claim $p^{\prime}$ was among BP then he wouldn't need to go to the trouble of telling a story that verifies $p^{\prime}$. Furthermore, it seems as though van Inwagen does need to tell such a story. As mentioned above given his materialist metaphysics of the human person 'it is absolutely impossible, even as an accomplishment of God, that a man who has been burned to ashes or been eaten by worms should ever live again' (van Inwagen 1998b, p. 48). Since it certainly seems that some human organisms or, at least, their remains, will be eaten by worms, this does seem to demonstrate, given van Inwagen's metaphysics, that it's absolutely impossible for God to restore these human organisms to existence. The assertion of the possibility-claim $p^{\prime}$, therefore, needs some sort of justification if it is to believed in the light of van Inwagen's materialist metaphysics.

Objection 4 van Inwagen might point out that, since conceivability arguments are subject-dependent, and given that what one subject takes to verify some proposition may be different from what another subject takes to verify that same proposition, $w^{\prime}$ can still serve to justify the assertion of the possible truth of $p^{\prime}$, so long as a particular subject takes $w^{\prime}$ to verify $p^{\prime}$. That is, so long as that particular subject is not a modal sceptic.

\footnotetext{
12 This objection is a version of (c) in footnote 7 (above).

13 He writes, for example, "how do we know "simple, obvious" modal statements to be true? What is the ground of "basic" modal knowledge? I do not know how to answer these questions' (van Inwagen 1998a, p. 74).
} 
Response: In response we should note that my aim in this paper has only been to show that one cannot accept van Inwagen's modal scepticism and van Inwagen's argument as put forward in 'The Possibility of Resurrection.' This, I think, has been achieved. It is, unfortunately, outside the scope of this paper to argue in favour of model scepticism (or something relevantly similar). In consequence, I leave it up to the reader to decide whether or not she find's van Inwagen's modal scepticism (or something similar) independently plausible. ${ }^{14}$

In sum, van Inwagen, in his argument for the possibility of the resurrection, fails to establish that it is possible for God to resurrect human organisms. This is because the world that van Inwagen describes in order to verify that it is possible for God to resurrect human organisms has neither been imagined in a sufficient amount of structural detail nor imagined in a way that rules out the possibility of its being the case that God does not resurrect a human organism, but only brings a new organism into existence.

Acknowledgments I would like to thank Daniel Hill and Stephen McLeod for their comments on an earlier draft of this piece. I would also like to thank Greg Miller for the many conversations we had about modal knowledge. They helped to strengthen the paper.

Open Access This article is distributed under the terms of the Creative Commons Attribution 4.0 International License (http://creativecommons.org/licenses/by/4.0/), which permits unrestricted use, distribution, and reproduction in any medium, provided you give appropriate credit to the original author(s) and the source, provide a link to the Creative Commons license, and indicate if changes were made.

\section{References}

Anders, P. C. (2011). Mind, mortality and material being: Van Inwagen and the dilemma of material survival of death. Sophia, 50(1), 25-37.

Atkinson, T. (2015). A reply to Anders' 'mind, mortality and material being: Van Inwagen and the dilemma of material survival of death. Sophia, 54(4), 577-592.

Eberl, J. T. (2008). Potentiality, possibility, and the irreversibility of death. The Review of Metaphysics, $62(1), 61-77$.

Gendler, T. S. (2002). Personal identity and thought-experiments. The Philosophical Quarterly, 52(206), 34-54. doi:10.1111/1467-9213.00251.

Gilmore, C. (2013). When do things die? In B. Bradley, F. Feldman, \& J. Johansson (Eds.), The Oxford handbook of the philosophy of death (pp. 1-59). Oxford handbooks in philosophy. New York: Oxford University Press.

Hartl, P. (2016). Modal scepticism, Yablo-style conceivability, and analogical reasoning. Synthese, 193(1), 269-291. doi:10.1007/s11229-015-0759-4.

Hasker, W. (2001). The emergent self. Ithaca, NY: Cornell University Press.

\footnotetext{
14 I might add that van Inwagen is not the only modal sceptic. There are a number of modal sceptics of a van Inwagenian sort, especially concerning matters of personal identity across time. As Paul Snowdon, for example, notes when considering the brain-transplant intuition, '[t]he link between imaginability and genuine metaphysical possibility has been thoroughly debated recently, with the result, as I see it, that imaginability cannot be taken as a guide to possibility' (Snowdon 2014, p. 207). See also (Wilkes 1993; Gendler 2002).
} 
Hawke, P. (2011). Van Inwagen's modal skepticism. Philosophical Studies, 153(3), 351-364. doi:10. 1007/s11098-010-9520-5.

Snowdon, P. F. (2014). Persons, animals, ourselves. New York: Oxford University Press.

van Inwagen, P. (1978). The possibility of resurrection. International Journal for Philosophy of Religion, 9(2), 114-121.

van Inwagen, P. (1990). Material beings. Ithaca; NY: Cornell University Press.

van Inwagen, P. (1995a). Dualism and materialism. Faith and Philosophy, 12(4), 475-488.

van Inwagen, P. (1995b). Introduction. In God, knowledge and mystery: Essays in philosophical theology (pp. 11-21). Ithaca: Cornell University Press.

van Inwagen, P. (1998a). Modal epistemology. Philosophical Studies, 92(1), 67-84.

van Inwagen, P. (1998b). The possibility of resurrection. In The possibility of resurrection and other essays in Christian apologetics (pp. 45-51). Boulder, CO: Westview Press.

Wilkes, K. V. (1993). Real people: Personal identity without thought experiments. Oxford: Clarendon. Yablo, S. (1993). Is conceivability a guide to possibility? Philosophy and Phenomenological Research, 53(1), 1. doi:10.2307/2108052.

Zimmerman, D. (2010). Bodily resurrection: The falling elevator model revisited. In G. Gasser (Ed.), Personal identity and resurrection: How do we survive our death? (pp. 35-50). Burlington, VT: Ashgate Pub. Co. 